\title{
Pengaruh Relaksasi Otot Progresif dengan Musik terhadap Kualitas Tidur Lansia di Posyandu Lansia "Anjasmoro" Kelurahan Sukorame Kediri
}

\author{
Setyoadi ${ }^{*}$, Retno Lestari ${ }^{*}$, Nirmala Kusuma*
}

\begin{abstract}
ABSTRAK
Kualitas tidur merupakan kepuasan tidur yaitu suatu keadaan istirahat badan dan pikiran (tidur nyenyak atau pulas) yang ditandai dengan badan terasa segar ketika bangun tidur. Kualitas tidur buruk akan mengakibatkan badan terasa lelah, tanda-tanda vital tidak stabil meskipun tidur dalam waktu yang lama. Tujuan penelitian ini adalah untuk menganalisis pengaruh relaksasi otot progresif dengan musik terhadap kualitas tidur lansia di Posyandu Lansia "Anjasmoro" Kelurahan Sukorame Kota Kediri. Penelitian ini menggunakan desain penelitian pre-experimental. Sampel penelitian adalah 17 orang lansia. Variabel bebas dalam penelitian ini adalah relaksasi otot progresif dengan musik. Variabel tergantung adalah kualitas tidur. Pengumpulan data dilakukan dengan cara observasi dan dianalisis menggunakan uji Wilcoxon. Hasil penelitian menunjukkan adanya pengaruh yang signifikan dari relaksasi otot progresif dengan musik terhadap kualitas tidur pada lansia di Posyandu Lansia Kelurahan Sukorame Kota Kediri $(p=0,000)$ Kesimpulan penelitian ini adalah relaksasi otot progresif dengan musik dapat meningkatkan kualitas tidur lansia.
\end{abstract}

Kata kunci: Kediri, Kelurahan Sukorame, kualitas tidur, Lansia, Musik, Relaksasi otot.

\section{The Effect of Progressive Muscle Relaxation with Music on Sleep Quality at Elderly Integrated Service Post "Anjasmoro" of Sukorame District Kediri}

\begin{abstract}
Sleep quality is satisfaction in sleep which is a resting state of body and mind (deep sleep or asleep) are characterized by the body feel refreshed when someone wake up. Poor quality in sleep will make the body feels tired, unstable vital signs eventhough have sleep in a long time. The purpose of this study was to analyze the effect of progressive muscle relaxation with music on sleep quality for elderly at Elderly Integrated Service Post "Anjasmoro" of Sukorame District Kediri City. The research used a pre-experimental design. The sample in this study was 17 elderly people. The independent variable in this study is progressive muscle relaxation with music. The dependent variable in this study is sleep quality. The result showed the significant relationship between progressive muscle relaxation with music and sleep quality in elderly at Elderly Integrated Service Post of Sukorame District Kediri City (Wilcoxon analysis, $p=0,000$ ). It can be concluded that progressive muscle relaxation with music could improve the quality of sleep in elderly.
\end{abstract}

Keywords: Elderly, Kediri, Muscle relaxation, Music, Sleep quality, Sukorame district.

* Program Studi llmu Keperawatan, FKUB 


\section{PENDAHULUAN}

Menua merupakan fenomena di seluruh dunia. Semua penduduk di dunia akan mengalami proses penuaan yang ditunjukkan dengan bertambahnya usia. Berdasarkan prediksi, pada tahun 2030, satu dari delapan orang di dunia, dapat mencapai usia di atas 65 tahun. ${ }^{1}$ Hal tersebut menggambarkan bahwa jumlah penduduk lanjut usia atau lansia akan semakin meningkat seiring bertambahnya tahun, termasuk di Indonesia yang diperkirakan pada tahun 2025 mencapai 32 sampai 36 juta orang atau $11,34 \%$ dari populasi penduduk. ${ }^{2}$

Jumlah lansia yang semakin meningkat merupakan suatu hal yang harus menjadi perhatian karena lansia dalam aspek fisik, psikologis dan sosialnya akan mengalami penurunan fungsi pula. $^{3}$ Aspek fisik khususnya pada sistem muskuloskeletal akan mengalami gerakan lebih kaku dan lambat, koordinasi menurun, sikap tubuh berubah atau lebih bongkok yang menyebabkan terbatasnya aktifitas. ${ }^{4}$ Keterbatasan aktifitas tersebut menyebabkan aliran darah kurang lancar. Selain itu, adanya perubahan sosial yang dialami lansia yaitu perubahan kondisi ekonomi bagi pensiunan sehingga pendapatan semakin menurun.

Adanya keterbatasan di atas, yaitu aliran darah yang kurang lancar karena perubahan fungsi muskuloskeletal dan kecemasan karena perubahan aspek psikologis dan sosial, maka akan berdampak pada perubahan fase tidur. Pada lansia, tidur dalam fase menghilang (fase 3 dan 4) dan tidur mimpi menjadi lebih panjang sehingga lansia akan sering terbangun. ${ }^{5}$ Berbeda dengan siklus tidur normal yang melalui beberapa fase, antara lain tidur tenang dan tidur mimpi. Fase tidur tenang dibedakan menjadi tidur dangkal (tahap 1) yaitu tidur yang masih mudah terbangun jika ada gangguan kecil, fase tidur sebenarnya (tahap 2) yaitu kondisi mulai masuk pada fase terlelap, dan fase tidur dalam (fase 3 dan 4) yaitu kondisi tidur yang sudah benarbenar terlelap. ${ }^{6}$

Siklus tidur yang tidak sempurna pada lansia menyebabkan lansia tidak tertidur pulas, sering terbangun, dan jumlah total waktu tidur per hari yang berkurang. Hal tersebut menyebabkan kualitas tidur lansia menurun. ${ }^{7}$

Gangguan tidur pada lansia dapat diperbaiki dengan teknik relaksasi otot progresif, yaitu teknik relaksasi yang memusatkan perhatian pada suatu aktivitas otot dengan mengidentifikasi otot yang tegang kemudian menurunkan ketegangan dengan melakukan teknik relaksasi untuk mendapatkan perasaan relaks. ${ }^{8}$ Penelitian terdahulu melaporkan bahwa responden yang diberikan terapi musik mengalami penurunan yang besar dalam tingkat kecemasan dan kelemahan dibandingkan dengan responden yang diberikan terapi relaksasi otot progresif tanpa diiringi dengan musik. ${ }^{10}$ Musik berperan vital dalam penurunan perasaan kelemahan dengan menstimulus kesenangan, dengan demikian dapat menciptakan sebuah rangsangan semangat pada seseorang yang melakukan relaksasi progresif.

Hasil studi pendahuluan pada lansia di Kelurahan Sukorame Kediri, hampir $80 \%$ dari lansia mengalami penurunan kualitas tidur. Banyak lansia yang mengeluhkan sulit untuk memulai tidur, terbangun di malam hari dan bangun terlalu pagi. Kondisi tersebut menunjukkan siklus tidur harian lansia di desa tersebut mengalami perubahan dibandingkan dengan siklus tidur harian secara normal. Berdasarkan masalah yang terjadi pada lansia di desa Sukorame Kediri di atas, maka ingin diketahui pengaruh relaksasi otot progresif dengan musik terhadap kualitas tidur lansia di Kelurahan Sukorame Kediri. 


\section{BAHAN DAN METODE}

Desain penelitian ini menggunakan pre experimental dengan pendekatan pretestposttest without control group, teknik sampling yang digunakan adalah purposive sampling. Dalam penelitian ini menggunakan sampel lansia di posyandu lansia Anjasmoro kelurahan Sukorame Kediri yang berusia di atas 60 tahun sebanyak 17 lansia yang telah memenuhi kriteria inklusi. Kriteria inklusi dalam penelitian ini adalah lansia peserta Posyandu Lansia Sukorame Kediri, berusia di atas 60 tahun, dan mempunyai kualitas tidur buruk. Penelitian ini dilakukan di rumah responden dengan empat kali terapi. Data diolah menggunakan uji Wilcoxon.

\section{HASIL}

\section{Karakteristik Responden Berdasarkan Usia}

Berdasarkan Tabel 1. dapat diketahui bahwa karakteristik usia responden berdasarkan batasan usia lansia di Posyandu Lansia "Anjasmoro" Kelurahan Sukorame, yaitu usia 61-75 tahun yang termasuk dalam lanjut usia (elderly) berjumlah 17 responden dengan usia paling rendah 61 tahun dan usia paling tua 75 tahun.

Tabel 1. Distribusi frekuensi karakteristik responden berdasarkan usia di Posyandu Lansia "Anjasmoro" Kelurahan Sukorame tahun 2015

\begin{tabular}{lccccc}
\hline Variabel & $\mathrm{N}$ & Mean & SD & $\begin{array}{c}\text { Min- } \\
\text { Max }\end{array}$ & $95 \% \mathrm{Cl}$ \\
\hline Usia & 17 & 68,05 & 4,6 & $61-$ & $65,69-$ \\
& & & & 75 & 70,42 \\
\hline
\end{tabular}

\section{Karakteristik Responden Berdasarkan Jenis Kelamin}

Berdasarkan Tabel 2. dapat diketahui bahwa jenis kelamin perempuan lebih banyak dibanding jenis kelamin laki-laki yaitu responden sebanyak 14 orang (82 \%), sedangkan responden laki-laki sebanyak 3 orang $(18 \%)$.

Tabel 2. Distribusi frekuensi karakteristik responden berdasarkan jenis kelamin di Posyandu Lansia "Anjasmoro" Kelurahan Sukorame tahun 2015

\begin{tabular}{lcc}
\hline Jenis kelamin & Jumlah & $\begin{array}{c}\text { Persentase } \\
(\%)\end{array}$ \\
\hline Laki-laki & 3 & 18 \\
Perempuan & 14 & 82 \\
Total & 17 & 100 \\
\hline
\end{tabular}

Nilai Kualitas Tidur Sebelum dan Sesudah Perlakuan

Berdasarkan Gambar 1, terdapat peningkatan kualitas tidur setelah dilakukan relaksasi otot progresif dengan musik. Peningkatan tersebut dari kategori buruk dengan skor $\geq 5$ menjadi baik dengan skor $\leq$ 5 , namun dari 17 responden tersebuat ada beberapa yang masih dalam rentang buruk, yaitu sejumlah 5 responden.

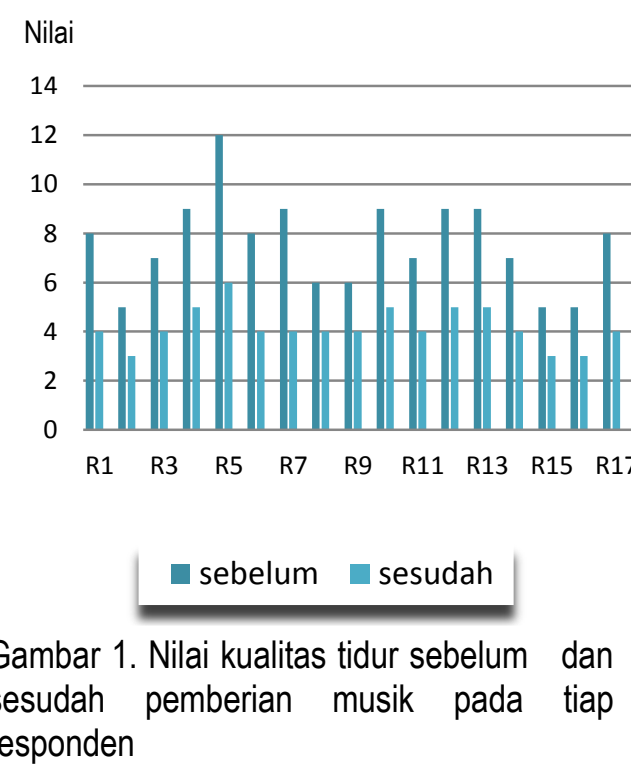




\section{Rata-Rata Nilai Kualitas Tidur Sebelum dan Sesudah Perlakuan Seluruh Responden}

Berdasarkan Gambar 2 dapat diketahui bahwa terjadi penurunan nilai rata-rata antara sebelum dengan sesudah dilakukan terapi. Hal ini menunjukkan bahwa terjadi perbaikan kualitas tidur setelah dilakukan terapi. Penurunan nilai tersebut sebesar 3,3 yaitu dari 7,5 menjadi 4,2 atau $25 \%$.

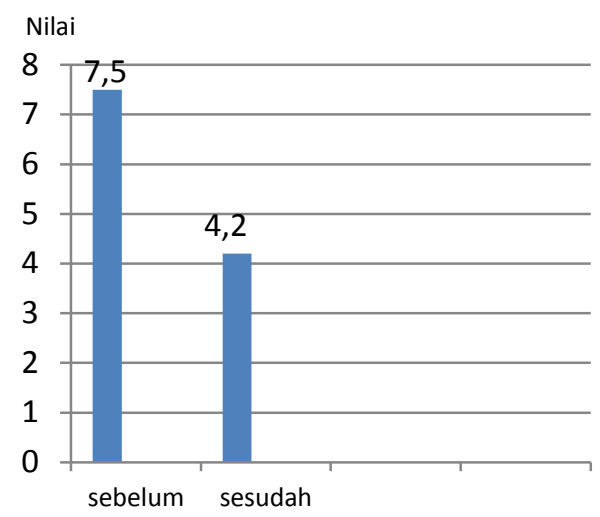

Gambar 2. Rata-rata nilai kualitas tidur sebelum dan sesudah pemberian musik pada seluruh responden

\section{Analisis Uji Wilcoxon}

Sebelum dilakukan uji hipotesis untuk mengetahui penurunan nilai kualitas tidur pada lansia di Posyandu Lansia Kelurahan Sukorame sebelum diberi terapi (pretes) dan setelah diberi terapi (postes), terlebih dahulu telah dilakukan uji normalitas data dengan menggunakan uji statistik shapiro-wilk menggunakan SPSS versi 16. Hasil uji normalitas didapatkan nilai signifikansi 0,149 yang berarti lebih besar dari $p=0,05$ pada data pretes dan nilai signifikansi 0,016 pada data postes yang berarti lebih kecil dari $p=$ 0,05 . Dari hasil uji normalitas tersebut dapat diartikan bahwa sebaran data tidak normal, sehingga dilanjutkan dengan uji Wilcoxon. Dari hasil analisis Wilcoxon didapatkan nilai $p=0,000$ yang berarti kurang dari $p=0,05$. $\mathrm{Hal}$ ini berarti $\mathrm{H} 1$ diterima atau ada perbedaan bermakna antara kelompok sebelum dan sesudah perlakuan.

\section{PEMBAHASAN}

\section{Kualitas Tidur Sebelum Terapi Relaksasi Otot Progresif dengan Musik}

Berdasarkan hasil penelitiian di atas diketahui bahwa seluruh responden (100\%) memiliki kualitas tidur yang buruk dan kesulitan untuk memulai tidur. Kemudian hampir semua menyatakan tidur selama 5-6 jam, terbangun di tengah malam dan terbangun karena harus ke kamar mandi. Lansia yang mempunyai kualitas tidur buruk terjadi karena adanya gangguan fisik, mental dan psikososial. ${ }^{10} \mathrm{Hal}$ tersebut juga terjadi pada lansia di Posyandu Lansia Kelurahan Sukorame Kediri. Gangguan fisik yang terjadi antara lain timbulnya penyakit seperti pegal-pegal, pusing, gatal-gatal dan penyakit lain seperti hipertensi. Gangguan mental yang terjadi pada lansia antara lain curiga, mudah marah dan egois. Gangguan psikososial berdasarkan pernyataan lansia yaitu kehilangan teman, jauh dari keluarga sehingga menyebabkan lansia merasa kesepian. Faktor tersebut dapat mempengaruhi kualitas tidur pada lansia.

Berdasarkan hasil penelitian diketahui bahwa usia responden adalah 61-75 tahun yang merupakan kategori lanjut usia. Lanjut usia akan mengalami perubahan fisik berupa penurunan fungsi organ sehingga rentan terhadap berbagai penyakit seperti nyeri pinggang, nyeri dada, nyeri sendi, pusing dan gangguan tidur. ${ }^{11} \mathrm{Hal}$ tersebut dapat terjadi pada lanjut usia karena adanya proses degenerasi dan hal ini dapat menyebabkan kualitas tidur tidak adekuat. ${ }^{12}$ Kualitas tidur yang kurang pada lanjut usia terjadi adanya penurunan yang progresif pada tahan tidur NREM 3 dan 4, beberapa lansia hampir tidak memiliki tahap tidur NREM 4 dan tidur yang dalam..$^{13}$ Akibat kualitas tidur yang kurang menyebabkan peningkatan kerja jantung dan saat bangun 
di pagi hari seseorang akan merasa tidak segar dan di siang hari merasa kelelahan atau sering mengantuk.

Berdasarakan hasil penelitian menunjukkan bahwa responden berjenis kelamin perempuan sebesar $82 \%$ memeiliki kualitas tidur buruk. Perempuan cenderung memiliki kualitas tidur buruk dibandingkan dengan laki-laki karena perempuan lebih sering mengalami gangguan pada faktor psikis seperti stres atau depresi. Perempuan menggunakan perasaan untuk mengekspresikan sesuatu sehingga perempuan lebih sering merasa takut, gelisah dan tertekan yang mengakibatkan stres. $^{2}$

\section{Kualitas Tidur Setelah Diberikan Terapi Relaksasi Otot Progresif dengan Musik}

Terapi relaksasi otot progresif dengan musik pada lansia, meningkatkan kualitas tidur (kualitas tidur menjadi baik) pada 12 responden dari 17 responden. Hal tersebut berdasarkan hasil kuesioner dari 17 responden $(100 \%)$ menyatakan tidak pernah meminum obat tidur untuk membantu tidurnya, 12 responden (71\%) tidak pernah menahan kantuk ketika bekerja dan 15 responden (88 \%) menyatakan kualitas tidurnya sangat baik. Jadi dapat disimpulkan terjadi peningkatan kualitas tidur lansia sesudah diberikan terapi relaksasi otot progresif dengan musik.

Peningkatan kualitas tidur pada lansia dapat dipengaruhi oleh lingkungan, gaya hidup dan obat-obatan. Lingkungan tempat tinggal lansia yang nyaman, suhu ruangan yang sesuai dan pencahayaan yang baik dapat meningkatkan kualitas tidur lansia. Gaya hidup lansia yang baik seperti olah raga secara teratur juga mempengaruhi kualitas tidur lansia yang akan membuat badan akan terasa lebih segar, tidak lemas dan tidak mudah kelelahan karena kondisi fisik yang baik. Sementara obat-obatan yang dikonsumsi secara terus menerus akan mengganggu kesehatan pada lansia yang telah rentan terhadap perubahan secara fisik maupun psikologi. Dengan lebih mengutamakan pada kebutuhan nutrisi atau makanan yang sehat maka lansia tidak perlu mengkonsumsu obat-obatan tertentu untuk membantu tidurnya. ${ }^{14} \mathrm{Hal}$ ini sesuai dengan pengamtan peneliti di Posyandu Lansia Kelurahan Sukorame Kediri yaitu sebanyak 17 orang (100 \%0 tidak pernah mengkonsumsi obat-obatan untuk membantu tidurnya. Penelitian sebelumnya menyatakan bahwa relaksasi otot progresif dengan musik yang dilakukan empat kali dalam dua minggu dapat meningkatkan kualitas tidur lansia. ${ }^{9}$ Musik yang digunakan dalam penelitian tersebut merupakan musik instrumental dengan tempo lamban. Tempo lamban dapat memberikan rangsangan pada korteks serebri (korteks auditorius primer dan sekunder) sehingga dapat menyeimbangkan gelombang otak menuju gelombang otak alpha yang menandakan ketenangan. ${ }^{15}$ Ketenangan yang ditimbulkan dari pemberian terapi musik membuat lansia nyaman dan rileks sehingga terjadi peningkatan pada kualitas tidur lansia yang awalnya buruk menjadi baik.

\section{Pengaruh Relaksasi Otot Progresif dengan Musik terhadap Kualitas Tidur Lansia}

Berdasarkan hasil penelitian diketahui ada pengaruh pemberian terapi relaksasi otot progresif dengan musik terhadap peningkatan kualitas tidur responden. Hal ini sesuai dengan teori bahwa terapi relaksasi otot progresif dengan musik dapat meningkatkan kualitas tidur lansia. ${ }^{9}$

Relaksasi otot progresif adalah cara yang efektif untuk relaksasi dan mengurangi kecemasan, jika seseorang mampu mengistirahatkan otot-ototnya melalui cara yang tepat, maka akan diikuti dengan relaksasi mental atau pikiran. Sementara musik berdasarkan prinsip kerjanya, musik 
yang didengar oleh telinga akan distimulasi ke otak, kemudian musik tersebut akan diterjemahkan menurut jenis musik dan target yang akan distimulasi. Gelombang suara yang dihantarkan ke otak akan membangkitkan gelombang otak alfa yang dapat membangkitkan relaksasi. ${ }^{16}$

Posisi rileks inilah yang menurunkan stimulus ke sistem aktivasi retikular (SAR) yang terletak pada batang otak teratas yang dapat mempertahankan kewaspadaan dan terjaga, dengan demikian akan diambil alih oleh bagian otak yang lain yang disebut BSR (bulbar synchronizing region) yang fungsinya berkebalikan dengan SAR, sehingga bisa menyebabkan tidur yang diharapkan akan dapat meningkatkan kualitas tidur. ${ }^{13}$

Pemberian terapi relaksasi otot progresif dengan musik dapat membantu dalam memenuhi kebutuhan tidur pada lansia baik secara kuantitas maupun kualitasnya. Pada penelitian ini peneliti berfokus pada kualitas tidur, namun banyak orang yang menganggap bahwa lamanya tidur akan membuat seseorang beristirahat dengan baik. Padahal dengan jam tidur yang terlalu banyak juga tidak akan bermanfaat bagi tubuh tanpa adanya kualitas tidur yang baik. Kualitas tidur seseorang dipengaruhi oleh faktor internal dan eksternal. Faktor internal adalah keadaan fisik dan psikologis yang pada seseorang berbeda satu sama lain, sehingga apabila terjadi perubahan fisik dan psikologis berupa penyakit dan gangguan mood dapat mempengaruhi kualitas tidur seseorang. Begitu pula dengan pengaruh faktor eksternal yang dialami seseorang berupa lingkungan tempat tinggal, perubahan suhu kamar tidur yang menyebabkan seseorang lebih mudah terbangun di tengah malam dan sulit untuk memulai tidur. Kualitas tidur adalah kepuasan seseorang terhadap tidur, sehingga seseorang tersebut tidak memperlihatkan perasaan lelah, gelisah, lesu dan apatis serta tidak adanya tanda kehitaman di sekitar mata, kelopak mata bengkak, konjungtiva merah, sakit kepala dan sering menguap atau mengantuk. ${ }^{17}$

Dampak yang terjadi apabila kualitas tidur terpenuhi, maka akan mengalami peningkatan kesehatan fisiologis maupun psikologis. Kesehatan fisiologis ditunjukkan dengan tidak pusing dan tidak merasa lesu setelah bangun tidur dan kesehatan psikologis ditunjukkan dengan tidak terjadi gangguan mood seperti mudah marah sehingga gejala-gejala yang menandakan kualitas tidur buruk menjadi menurun bahkan tidak terjadi.

Terapi relaksasi otot progresif dengan musik saling berkaitan. Hasil yang didapat dari pemberian terapi tersebut dapat membuat seseorang mnejadi rileks dan suasana hati senang. Sehingga, adanya pengaruh tersebut maka membuat lansia mudah untuk tertidur dengan nyenyak dan kualitas tidur menjadi baik.

\section{KESIMPULAN}

Penelitian ini menyimpulkan bahwa relaksasi otot progresif dengan musik dapat meningkatkan kualitas tidur lansia. Sebanyak 17 orang (100 \%) mengalami kualitas tidur buruk sebelum diberikan terapi relaksasi otot progresif dengan musik, dan sesudah diberikan terapi sebanyak 12 orang $(71 \%)$ mengalami kualitas tidur baik.

\section{DAFTAR PUSTAKA}

1. Van Leuven. Population Aging: Implications for Nurse Practitioners. Journal for Nurse Practitioners. (Online). 2012; 8(7): 554-559, (http://dx.doi.org/10.1016/..nurpra.2012. 02.006. Diakses 5 Oktober 2014.

2. Widiyani R. Tahun 2025 , Jumlah Lansia Melebihi Balita. http://health.kompas.com/read/2013/06/ 
01/08561583/Tahun.2025.Jumlah.Lansi a.Melebihi.Balita. 2013.

3. Maryam S dkk. Mengenal Usia Lanjut dan Perawatannya. Jakarta: Salemba Medika. 2008.

4. Tambayong. Patofisiologi untuk Keperawatan. Jakarta: EGC. 2000.

5. Tjai R. Obat-Obat Penting Kasiat, Penggunaan dan Efek-Efek Sampingnya. Edisi ke-4. Jakarta: PT Elex Media Komputindo. 2007. HIm 383.

6. Apriadji. Good Mood Food Makanan Sehat Alami. Jakarta: Gramedia Pustaka Utama. 2007. HIm 41.

7. Tamher S dkk. Kesehatan Usia Lanjut dengan Pendekatan Asuhan Keperawatan. Jakarta: Salemba Medika. 2009.

8. Herodes. Teknik Relaksasi Progresif terhadap Insomnia pada Lansia. (Online).2010.(http://herodessolution.blo gspot.com/2010/11/teknik-relaksasiprogresif-terhadap. Diakses 5 Oktober 2014.

9. Choi YK. The Effect of Music and Progressive Muscle Relaxation on Anxiety, Fatigue, and Quality of Life in Family Caregivers of Hospice Patients. (Online). 2010. (http://search.proquest.com/docview/22 3548209/fulltextPDF/34F7BCCDA76E4 C86PQ/1? accountid $=46437$. Diakses 5 Oktober 2014.

10. Anwar Z. Penanganan Gangguan Tidur pada Lansia. (Online). 2010. (http://researchreport.umm.ac.id/index.p hp/researchreport/article/viewfile/341/43 5ummresearchreportfulltext.pdf).

Diakses 1 Maret 2015.

11. Bandiyah S. Lanjut Usia dan Keperawatan Gerontik. Yogyakarta: Nuha Medika. 2009.

12. Erliana E, Harun $H$, \& Susanti RD. Perbedaan Tingkat Insomnia Lansia Sebelum dan Sesudah Latihan Relaksasi Otot Progresif di BPSTW Ciparay Bandung. (Online). 2008. (http://www.kesehatan.lansia.com/2009/ tingkat-insomnia-pada-lansia.pdf).

Diakses 1 Maret 2015,

13. Potter PA dan Perry AG. Buku Ajar Fundamental Keperawatan: Konsep, Proses dan Praktik. Jakarta: EGC. 2006.

14. Siregar. Mengenal Sebab-Sebab, Akibat-Akibat dan Cara Terapi Insomnia. Jogjakarta: Flash Books. 2011.

15. Wijayanti FY. Perbedaan Tingkat Insomnia pada Lansia Sebelum dan Sesudah Pemberian Terapi Musik Keroncong di Pelayanan Sosial Lanjut Usia Tulungagung. Skripsi. Universitas Brawijaya. Malang. 2012.

16. Stefanus K. Pengaruh Terapi Musik terhadap Tingkat Depresi pada Lansia di Panti Wreda Hanna Yogyakarta. (Online). 2011. http://kristostefanus.wordpress.com. Diakses 5 Oktober 2014.

17. Hidayat A. Pengantar Kebutuhan Dasar Manusia: Aplikasi Konsep Dan Proses Keperawatan. Jakarta: Salemba Medika. 2006. 